\title{
EVALUATION OF NEW NON-TRADITIONAL PRODUCTS PROCESSED FROM CAPE GOOSEBERRY (PHYSALIS PERUVIANA L.)
}

\author{
REDA A. AAMER \\ Hort. Crop Technology Res. Department, Food Technology Research Institute, A.R.C., Egypt
}

(Manuscript received 5 August 2018)

\begin{abstract}
$\mathrm{C}$ ape gooseberry (Physalis peruviana, L.) is considered to be a very promising horticultural crop known in Egypt as Harankash as well as gaining popularity in the specialty markets. Currently it is usually used for local consumption in Egypt as a snack food. Therefore this current research aimed to utilize such crop by preparing and evaluating some food products such as canned compote, dehydrated fruits, nectar, syrup, paste, jam and appetizers. General characteristics, physical, chemical and technological properties, and some bioactive compounds of cape gooseberry (Physalis peruviana, L.) were investigated. The cape gooseberry pulp has a light sweet taste (TSS 13.75) with acidic nature (pH 3.7 and titratable acidity was $1.20 \%$ as citric acid), Non reducing sugars represented about (52.95\%) of the total sugars which were $(56.24 \%)$. The results also indicated that cape gooseberry can be considered as good source B-carotene, vitamin $\mathrm{C}$, total phenolic content, flavonoid contents and antioxidant activity in addition to some minerals such as potassium, magnesium, iron and zinc. The cape gooseberry (Physalis peruviana, L.) was used to formulate some important functional foods. The organoleptic properties of all processed products in this study were well palatable among different panelists.

Keywords: Cape gooseberry (Physalis peruviana, L.), snack food, bioactive compounds physical, chemical, technological and sensory properties.
\end{abstract}

\section{INTRODUCTION}

Development consumer demand for new crops as a purpose of diversification, especially if it can be used for different purposes i. e., local consumption, exportation and processing (Abeer, 2016). Also, today's consumers are very interested in the potential benefits of nutritional support for disease control or prevention through consuming healthy diet (Hassanien, 2011).

Cape gooseberry (Physalis peruviana, L.) is one of the important 100 species in the Physalis genus of the Solanaceae family. Physalis is included in the priority list of many governments' horticulture and fruit export plans. It is relatively unknown in importing markets and remains an exotic fruit. The important step toward developing Physalis as a commercial crop was maximizing its technological applications (ElSheikha et al., 2009) 
Cape gooseberry (Physalis peruviana, L.) is a very promising horticultural crop also known as poha, golden berry, Husk tomato, tomatillo, alkekengi, ground cherry and commonly known in Egypt as Harankash, this fruit is gaining popularity in the specialty markets. It is grown not only as a fruit which is eaten raw or as a dessert, jams, dehydrated fruits, sauces, appetizers, salads, cooked dishes, natural snacks and sometimes it is canned in heavy sugar syrup or used as dish decorations but also for its nutritional value i.e., it contains $\beta$-carotene (pro-vitamin $A$ ), phosphorus, iron, potassium, zinc, calcium, fatty acids (linoleic, oleic, palmitic and stearic acids), vitamin C (ascorbic acid) and polyphenols. The latter confer antioxidant activity (Puente et al., 2011).

Cape gooseberry(Physalis peruviana, L.) is a non-traditional horticultural crop in Egypt, it is widely used in folk medicine as a diuretic, for treating diseases such as malaria, asthma, hepatitis, dermatitis and rheumatism(Wu et al., 2005), and it has very positive effects for human health, highlighting medicinal properties as an antispasmodic, antiseptic, sedative, analgesic, in addition, it helps to strengthen the optic nerve, relieves throat problems and eliminates intestinal parasites and amoebas (Puente et al., 2011). Further, it secretes the bile juice and activates the liver function (Stary, 1983). Also, it shows antibiotic activity (Perry \& Metzger, 1980). The high $\beta$ carotene content of cape gooseberry has the potential of having anti-carcinogenic and antioxidant effects (Steinmetz and potter 1996). Nowadays, it is used in homeopathy for the same purpose. Nutritional considerations and health benefits bring the cape gooseberry to the forefront. Therefore, in Egypt, a great attention is directed for promoting this promising crop to meet the progressive demand of local fresh markets, medicinal purposes, developing processing industry and rapid growing of exportation (Mustafa, 2009).

Despite the healthy benefits of this fruit, Egypt still cultivated this fruit in a limited area compared to other common fruits. In addition, no attention has been paid to utilize the fruits of this plant in food industries. Thus, this work aimed to prepare and evaluate a new processed and non-traditional product (which was not processed before from this fruit) such as nectar, syrup, canned whole fruits in light syrup, jam, paste, dehydrated fruits and some kinds of appetizers. Consequently these new processed products could extend the marketing season for cape gooseberry all over the year, for the public consumers and also create opportunities to export those products to other countries. 


\section{MATERIALS AND METHODS}

\section{Materials:}

Cape gooseberry (Physalis peruviana, L) was purchased from the culture near Alexandria Governorate, Egypt. The general appearance of the whole fruit and berries of cape gooseberry fruit are illustrated in Fig. (1). Food ingredients including sugar, salt, vinegar, sunflower oil, cloves, chili, cinnamon, curcumins, garlic and onion powder, black seed, fresh pepper, fresh onion, fresh garlic, olive pickles were purchased from Alexandria market, Egypt. Pectin, carboxymethyl cellulose, xanthan gum, sodium benzoate, potassium sorbate, all chemicals and reagents used in the present study were purchased from El-Gomhouria Co., for Chemical and Medical Requisites, Alexandria, Egypt. Sodium metabisulphite and sodium chloride were obtained from El-Nasr Company. Glass jars and bottles were obtained from Edfina Company for Preserved Foods, Alexandria governorate, Egypt.

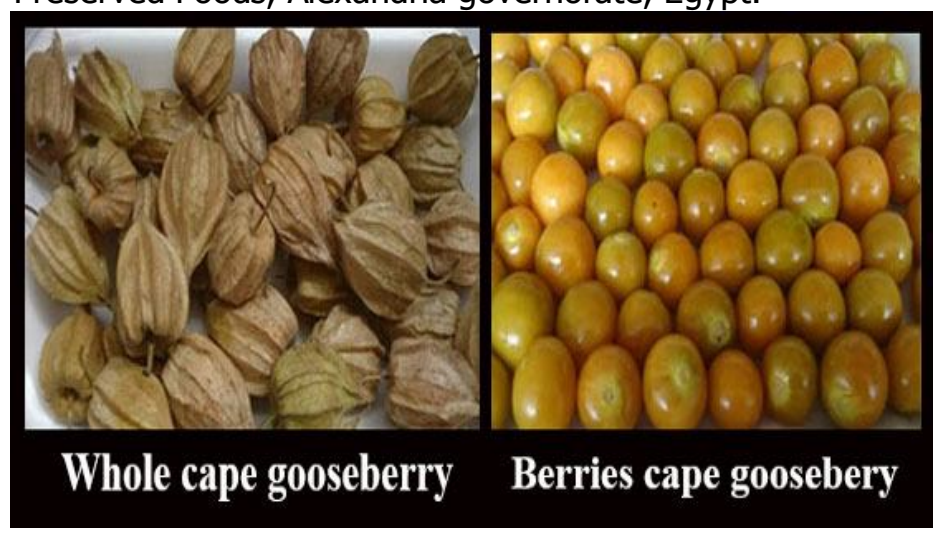

Fig. 1. General appearance of whole and berries cape gooseberry

\section{Methods}

\section{Physical methods}

Shape, skin colour, pulp colour, taste and texture of cape gooseberry fruits were visually described. Number of fruits/ $\mathrm{kg}$, average fruit weight ( $\mathrm{g} /$ fruit) and average fruit volume ( $\mathrm{cm}^{3} /$ fruit) were determined as mentioned by Kramer \& Twigg (1970). Sizes of fruits were measured using vernier calipers (Kanon Instruments, Japan) with an accuracy of $0.1 \mathrm{~mm}$. The density was calculated as mass/volume of a fruit (Khurmi, 1982). In addition, husk, yield after dehusking, juice, seeds and skin of cape gooseberry fruits were weighed by a top loading balance (model: D0001-HR120, AQD company, Limited EC).

Colour of cape gooseberry fruit sample was observed visually and measured with a Hunter Lab Colourimeter (Ultra scan vis, USA) as outlined by Piggott (1984). The $\mathrm{pH}$ value was determined using glass electrode $\mathrm{pH}$ meter (Persica model $\mathrm{pH}$ 900, Switzerland) as described in the AOAC (2003). The content of total soluble solids (TSS) at ambient temp expressed as ${ }^{\circ}$ Brix was determined using a digital 
refractometer (Hanna, HI 96811, Germany) as described in the AOAC (2003). Viscosity of the pulp and juice of cape gooseberry was determined by using a Brookfield Viscometer (model DV-II + Pro, Brookfield Engineering Laboratories, Middleboro, MA, USA) at $24.8^{\circ} \mathrm{C}$ with spindle number SC3- 15 after 30 s rotation of 5 rpm (Swami et al., 2013)

\section{Chemical Methods}

\section{Proximate chemical composition}

Moisture, crude protein, crude ether extract, crude fiber, ash and total, reducing and non-reducing sugars were determined according to the AOAC (2003) unless otherwise stated. Nitrogen free extract was calculated by difference. Titratable acidity as \% citric acid was determined according to AOAC (2003). Energy value was calculated using the universally acceptable conversion factors by multiplying protein and carbohydrates by 4.00 and fat by $9.00 \mathrm{Kcal} / \mathrm{g}$.

\section{Mineral composition}

Minerals including $\mathrm{K}, \mathrm{Mg}, \mathrm{Fe}, \mathrm{Mn}$ and $\mathrm{Zn}$ were determined according to the method described in AOAC (2000) method.

\section{Bioactive Compounds}

\section{Determination of ascorbic acid}

Ascorbic acid was determined using 2,6-dichloroindophenol by the AOAC (2003)

\section{Determination of $\beta$-carotene}

The total carotenoids content was determined in the acetone extract and measured spectrophotometrically at $440 \mathrm{~nm}$ as (mg/g) by the AOAC (2003).

\section{Determination of A, B and total chlorophyll}

Chlorophyll ( $a, b$ and total) were determined from fresh tissues of the cape gooseberry according to the method described by Moran \& Porath (1980) using N,Ndimethyl formamide (DMF).

\section{Determination of total phenols, flavonoid content and antioxidant activity}

One $\mathrm{g}$ sample was mixed with $10 \mathrm{ml}$ of $80 \%$ methanol and stirred at room temperature for $24 \mathrm{~h}$ and filtered. Total phenols, flavonoid content and antioxidant activity were determined in the methanolic extract.

The total phenolic content as ( $\mathrm{mg}$ gallic acid $/ 100 \mathrm{~g}$ ) was determined by FolinCiocalteu reagent after extracting with $80 \%$ methanol according to the method of Maurya \& Singh (2010). Total flavonoid content as (mg rutin /100g) was determined according to the method of Zarina \& Tan (2013).

Antioxidant activity of the samples after extracting with $80 \%$ methanol was determined by scavenging the radicals with 2,2-diphenyl-1-picrylhydrazyl- hydrate 
(DPPH) as described by Brand Williams et al., (1995) and expressed as percentage inhibition of the DPPH radical.

\section{Technological methods}

Cape gooseberry samples were manually dehusked, sorted to select the ripe and intact fruits and graded up to their colour, then washed with tap water and drained. dehusked cape gooseberry fruits were divided into three parts and the process was completed as follows

Part one (1): Whole fruits were used for processing dehydrated and canned compote fruits

Part two (2): Fruits were pulped using a fruit pulper (Kenwood major titanium, Japan) and the pulp was used to prepare jam, syrup and appetizers A, B. The pulp obtained was stored at $-18^{\circ} \mathrm{C}$ until used.

Part three (3): The extracted pulp was filtrated through a cheese cloth to separate the seeds and skins then it was used for the processing of nectar, paste. The fruit juice was stored at $-18^{\circ} \mathrm{C}$ until used.

Table (1) shows the Proportions of the different ingredients used for preparing compote, dehydrated fruits, nectar, paste, syrup, jam and appetizer (A, B) according to the recipes recommended by Edfina Company for Preserved Foods, Alexandria, Egypt. Meanwhile, Fig (2) illustrates the flow sheet of processing such products. All products in this study were manufactured in Edfina Company for Preserved Food, Alexandria, Egypt.

\section{Sensory evaluation}

Colour, odour, taste, texture and overall palatability of the products were assessed using 10 panelists from the Food Technol. Lab., Food Technol. Research Inst., Agriculture Research Center, of Sabahia, Alexandria, Egypt. The panelists were asked to score the above attributes according to a standard hedonic rating scale from 9 (like extremely) to 1 (dislike extremely) according to (Walts et al., 1989). 
EVALUATION OF NEW NON-TRADITIONAL

PRODUCTS PROCESSED FROM CAPE GOOSEBERRY

(PHYSALIS PERUVIANA L.)

Table 1. Proportions of the different ingredients used in preparing some cape gooseberry products

\begin{tabular}{|c|c|c|c|c|c|c|c|c|}
\hline \multirow{3}{*}{ Ingredient (g) } & \multicolumn{8}{|c|}{ Cape gooseberry products } \\
\hline & \multicolumn{2}{|c|}{ Whole } & \multicolumn{2}{|c|}{ Juice } & \multicolumn{4}{|c|}{ Pulp } \\
\hline & Compote & $\begin{array}{l}\text { Dehydrated } \\
\text { fruits }\end{array}$ & Nectar & Paste & Syrup & Jam & $\begin{array}{c}\text { Appetizer } \\
(A)^{*}\end{array}$ & $\begin{array}{c}\text { Appetizer } \\
(\mathrm{B})^{* *}\end{array}$ \\
\hline Whole cape gooseberry & 240 & 1000 & - & - & - & - & - & - \\
\hline Cape gooseberry pulp & - & - & - & - & 450 & 350 & 652 & 780 \\
\hline Cape gooseberry Juice & - & - & 200 & - & - & - & - & - \\
\hline $\begin{array}{l}\text { Cape gooseberry Juice ( } 20 \\
\%)\end{array}$ & - & - & - & 750 & - & - & - & - \\
\hline Sugar & 180 & - & 125 & 300 & 410 & 642 & - & 125 \\
\hline C.M.C & - & - & 2 & - & 2 & - & - & - \\
\hline Xanthan gum & - & - & 1 & - & 1 & - & 1 & 2.5 \\
\hline Carrageenan & - & - & - & 4.5 & - & - & - & - \\
\hline Pectin & - & - & - & - & - & 5.5 & - & - \\
\hline Citric acid & - & - & - & - & - & 2.5 & - & - \\
\hline Sodium benzoate & - & - & - & - & 0.4 & - & - & - \\
\hline Potassium sorbate & 0.5 & - & - & 0.37 & 0.6 & - & - & 0.5 \\
\hline Water & 579.5 & - & 672 & - & 136 & - & - & - \\
\hline Salt & - & - & - & - & - & - & 5 & 20 \\
\hline Natural vingar (5\%) & - & - & - & - & - & - & - & 60 \\
\hline Sunflower oil & - & - & - & - & - & - & 100 & - \\
\hline Cloves powder & - & - & - & - & - & - & - & 2.5 \\
\hline Cinnamon powder & - & - & - & - & - & - & - & 4 \\
\hline Curcumins powder & - & - & - & - & - & - & 1.5 & - \\
\hline Onion powder & - & - & - & - & - & - & - & 3 \\
\hline Garlic powder & - & - & - & - & - & - & - & 2.5 \\
\hline Fresh cut pepper & - & - & - & - & - & - & 80 & - \\
\hline Fresh cut onion & - & - & - & - & - & - & 80 & - \\
\hline Fresh cut garlic & - & - & - & - & - & - & 30 & - \\
\hline Olive Pickles & - & - & - & - & - & - & 50 & - \\
\hline Monoglycerides 90 & & - & - & & - & - & 0.5 & - \\
\hline Sodium carbonate (\%) & & 3 & & & & & & \\
\hline sodium metabisulphite (\%) & & 0.1 & & & & & & \\
\hline
\end{tabular}

Appetizer (A)*: Cape gooseberry sauce with vegetables

Appetizer (B)**: Cape gooseberry sauce with ketchup spices 
高

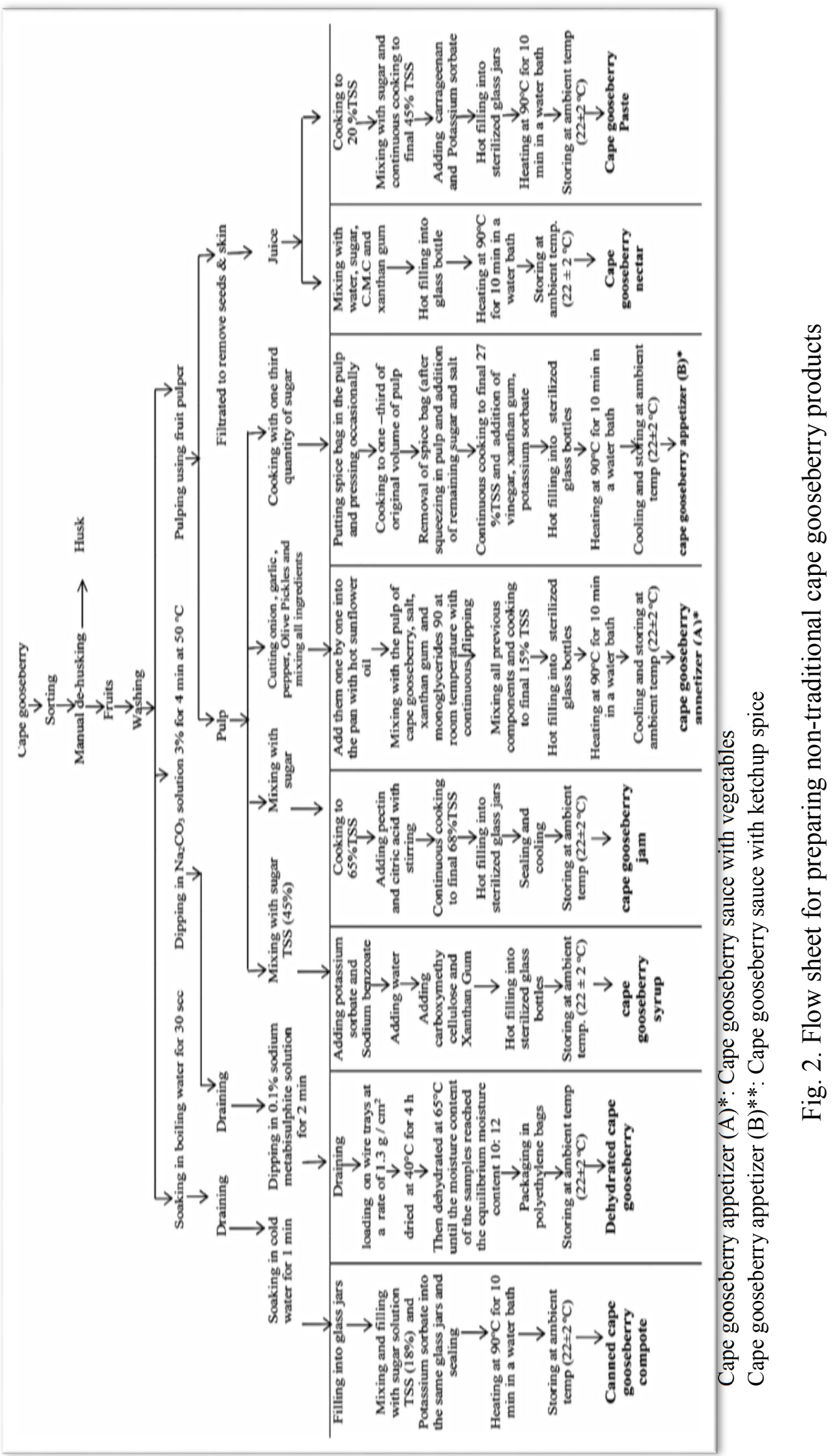




\section{RESULTS AND DISCUSSION}

\section{Fruit properties}

As shown in Table (2), the shape of the fresh cape gooseberry fruit was berry (small round).Skin and pulp colour were orange- yellow greenish colour. Fruit taste was light sweet and acidic. The parts used of cape gooseberry fruit were whole fruit without husk (pulp, seeds and skin) and the fruit texture was smooth and waxy.

Table 2. Appearance, physical and technological properties of fresh cape gooseberry

\begin{tabular}{|c|c|}
\hline Properties & Description \\
\hline \multicolumn{2}{|l|}{ 1- Appearance properties* } \\
\hline Shape & Berry ( small round) \\
\hline Skin colour & Orange- yellow greenish \\
\hline Pulp colour & Orange -yellow greenish \\
\hline Taste & light sweet and acidic taste \\
\hline Fruit texture & Smooth and waxy \\
\hline Parts used & Whole fruit without husk (pulp, seeds and skin) \\
\hline & Value \\
\hline \multicolumn{2}{|l|}{ 2- physical properties* } \\
\hline Number of fruit / kg & $213.33 \pm 0.58$ \\
\hline Average fruit weight (g/fruit) & $4.69 \pm 0.73$ \\
\hline Average fruit volume ( $\mathrm{cm}^{3} /$ fruit ) & $4.28 \pm 0.95$ \\
\hline Average diameter $(\mathrm{cm})$ & $1.95 \pm 0.064$ \\
\hline Fruit density $\left(\mathrm{g} / \mathrm{cm}^{3}\right)$ & $1.10 \pm 0.84$ \\
\hline \multicolumn{2}{|l|}{ 4- Technological properties $* *$} \\
\hline \multicolumn{2}{|l|}{ Husk (\%) } \\
\hline Pulp yield after dehusking (\%) & $8.02 \pm 0.68$ \\
\hline Extracted Juice (\%) & $91.98 \pm 0.68$ \\
\hline Seeds and skin (\%) & $79 \pm 1.0$ \\
\hline \multirow[t]{2}{*}{ Extracted juice / seeds and skin ratio } & $21 \pm 1.0$ \\
\hline & $3.76 \pm 0.23$ \\
\hline
\end{tabular}

*Results are mean value of 10 determination \pm standard deviation.

** Results are mean value of 3 determination \pm standard deviation

The data in Table (2) reveal that the number of fruits $/ \mathrm{kg}$, average fruit weight , volume and diameter were $213.33 \mathrm{fruit} / \mathrm{kg}, 4.69 \mathrm{~g} /$ fruit , $4.28 \mathrm{~cm} 3 /$ fruit and 1.95 $\mathrm{cm}$, respectively. The percentage of husk was $8.02 \%$ and pulp yield after dehusking was $91.98 \%$. The extracted juice represents $79 \%$ while the seeds and skins together amount were $21 \%$ of the whole fruit., the juice/seeds and skins ratio was relatively high (3.76).The obtained results are not in accordance with those reported by AbouGharbia \& Abou-Tour (2001), Bakry (2003) and Abou-Farrag et al. (2013) which may be due to species, environmental and agricultural conditions as well as time of harvesting. The obtained result indicated that the fruit density $\left(\mathrm{g} / \mathrm{cm}^{3}\right)$ was $1.10, \mathrm{El}$ Sheikha et al. (2008) found a similar result for the variety Physalis pubescens in which the fruits density was $1.10\left(\mathrm{~g} / \mathrm{cm}^{3}\right)$. 


\section{Physical and chemical properties of fresh cape gooseberry}

Physical and chemical properties of cape gooseberry are shown in Table (3). Total solids (TS), total soluble solids (TSS) and pH values of cape gooseberry fruit were $15.86 \%, 13.75{ }^{\circ}$ Brix and 3.7, respectively. The percentage of TSS and $\mathrm{pH}$ values were close to that reported by Abou-Gharbia \& Abou-Tour (2001) and El Sheikha et al. (2008) and were higher than that presented by Abou-Farrag et al. (2013). The difference between total solids and total soluble solids is mainly due to the insoluble pectin and fibers.

Table (3) also shows the values for chromaticity coordinates: the cartesian coordinates ( $L^{*}, a^{*}$ and $\left.b^{*}\right)$. The coordinate $L^{*}$ corresponds to a value of 50.39 and allows to conclude that the berries are clear, because the value is closer to 100 (white) than to 0 (black).Comparing with the results obtained by Solange et al. (2015), it was found that the berries in the present work are slightly clearer than those analyzed by the authors, ( $L^{*}$ value of 65.72 ). The coordinate a* was found to be 16.69. This coordinate correspond to red colour when positive, as in the present case, and the redness is more intense as the value increases. In accordance with the results obtained in the present study the coordinate a* was found to be 16.69 in Solange et al. (2015) study. Hence, the berries evaluated in this work have a slightly more intense red colouration. The value of the coordinate $b *$ is 39.66 , and because it is positive lies within the colour spectrum of yellow. Comparing with the results of Solange et al. (2015), who reported values for this coordinate being 58.11, the slight differences found in the colour coordinates may naturally occur due to different maturity stages, cultivar or cultivation procedures. Also, as shown in Table (3), the viscosity of cape gooseberry fruit pulp and juice were 3300 and $600 \mathrm{cp}$. The difference between these values is due to the pulp that contains peels and seeds, while the juice that is free of them.

Table 3. Physicochemical properties of fresh cape gooseberry (fresh weight basis)

\begin{tabular}{|l|l|}
\hline \multicolumn{1}{|c|}{ Properties } & \multicolumn{1}{|c|}{ Value } \\
\hline Total solids * (TS) \% & $15.86 \pm 0.67$ \\
Total soluble solids * (TSS) ${ }^{\circ}$ Brix & $13.75 \pm 0.96$ \\
$\mathrm{PH}^{*}$ & $3.7 \pm 0.10$ \\
& \\
Hunter Lab measurements & \\
$L$ & 50.39 \\
$a$ & 17.80 \\
$b$ & 39.66 \\
& \\
Viscosity of pulp & $3300 \mathrm{cP}$ \\
Viscosity of juice & $600 \mathrm{cP}$ \\
\hline *Means of three replicates \pm S.D & \\
cP: centipoise &
\end{tabular}




\section{Chemical composition and mineral contents of fresh cape gooseberry}

The proximate chemical composition of fresh cape gooseberry on both fresh and dry weight basis are shown in Table (4). It could be noticed that the moisture content in cape gooseberry was $84.14 \%$, this value was higher than $80.7 \%$ and 81.49 reported by Abou-Gharbia \& Abou- Tour (2001) and Abou-Farrag et al. (2013) for $P$. pruinosa fruits . Also it can be noted that the crude protein $(10.21 \%)$ was lower than that reported by Abou-Farrag et al. (2013) (12.75\%) for P. pruinosa fruits and El Sheikha (2008) (13.18\%) for Physalis pubescens. Crude ether extract of fresh cape gooseberry was $7.39 \%$ on dry weight basis. This value disagreed with the value reported by Abou-Gharbia \& Abou-Tour (2001) and Abou-Farrag et al. (2013). They reported that crude ether extract was $5.70 \%$ and $4.96 \%$ (on dry weight basis). On the other hand, the obtained value was higher than that reported by Bakry (2003), who found that the crude ether extract content of cape gooseberry was $0.44 \%$ on dry weight basis. Total ash content of cape gooseberry was $7.97 \%$ on dry weight basis. This value was higher than that presented by Abou-Gharbia \& Abou-Tour (2001) (5.70\%) and Abou-Farrag et al. (2013) (5.98\%). On the other hand, crude fiber of cape gooseberry was $16.36 \%$ on dry weight basis. This value was lower than that reported by Bakry (2003) and Abou-Farrag et al. (2013).

The results of nitrogen free extract (58.07\%) were close to that reported by Abou-Farrag et al. (2013) (56.93\%). Moreover, the sugars (total, reducing and nonreducing) were $56.24,26.51$ and $29.78 \%$ on dry weight basis, respectively. Although, the total sugars were very close to that found by Bakry (2003) (54.22\%) and AbouFarrag et al. (2013) (54.22\%). Reducing sugars were higher than that reported by Abou-Gharbia \& Abou-Tour (2001) and Bakry (2003). The obtained results indicated that non-reducing sugars represented about $52.95 \%$ of the total sugars. These results agreed with those reported by Abou-Farrag et al. (2013). The energy value was 53.86 and 339.63 expressed as $\mathrm{Kcal} / 100 \mathrm{~g}$ sample on fresh and dry weight basis respectively. This result was lower than that found by Rodrigues et al. (2009) (88.72 $\mathrm{Kcal} / 100 \mathrm{~g}$ sample on fresh weight basis)

Total titratable acidity (TA) of fruits was $1.20 \%$ on fresh weight basis. This TA value is similar to that reported by Abou-Gharbia \& Abou- Tour (2001) for $P$. pruinosa as well as El Sheikha et al. (2008) for p. pubescens the same species.

Mineral contents of fresh cape gooseberry that included $\mathrm{K}, \mathrm{Mg}, \mathrm{Mn}, \mathrm{Fe}$, and Zn were 4346, 411.9, 1.24, 21.48 and 22.06 ppm (on dry weight basis), respectively. These values were higher than that reported by Bakry (2003) and Abou-Farrag et al. (2013). 
Table 4. Chemical composition and mineral contents of fresh cape gooseberry (fresh and dry weight basis)

\begin{tabular}{|c|c|c|}
\hline \multirow[b]{2}{*}{ Component } & \multicolumn{2}{|c|}{ Value* } \\
\hline & fresh weight basis (\%) & dry weight basis (\%) \\
\hline Moisture & $84.14 \pm 0.67$ & $\longrightarrow$ \\
\hline Crude protein & $1.62 \pm 0.17$ & $10.21 \pm 0.17$ \\
\hline Crude ether extract & $1.17 \pm 0.34$ & $7.39 \pm 0.34$ \\
\hline Total Ash & $1.26 \pm 0.188$ & $7.97 \pm 0.188$ \\
\hline Crude fiber & $2.60 \pm 0.10$ & $16.36 \pm 0.10$ \\
\hline Nitrogen free extract $* *$ & $9.21 \pm 0.34$ & $58.07 \pm 0.34$ \\
\hline Total sugars & $8.92 \pm 1.52$ & $56.24 \pm 1.52$ \\
\hline Reducing sugars & $4.20 \pm 1.34$ & $26.51 \pm 1.34$ \\
\hline Non reducing sugars & $4.72 \pm 1.45$ & $29.78 \pm 1.45$ \\
\hline Titratable acidity*** & $1.20 \pm 0.06$ & 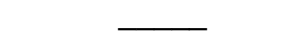 \\
\hline Energy value (Kcal /100g) & $53.86 \pm 0.28$ & $339.63 \pm 0.28$ \\
\hline \multicolumn{3}{|l|}{ Minerals (ppm) } \\
\hline K & 689.28 & 4346 \\
\hline $\mathrm{Mg}$ & 65.33 & 411.9 \\
\hline $\mathrm{Mn}$ & 0.20 & 1.24 \\
\hline $\mathrm{Fe}$ & 3.41 & 21.48 \\
\hline $\mathrm{Zn}$ & 3.50 & 22.06 \\
\hline
\end{tabular}

\section{Bioactive compounds of fresh cape gooseberry}

The total phenolic content, total flavonoids, antioxidant activity, ascorbic acid, B-carotene, total chlorophyll, chlorophyll A and B of cape gooseberry are shown in Table (5). The results showed that cape gooseberry had high amounts of phenolic content being $669.80 \mathrm{mg}$ GAE / $100 \mathrm{~g}$ dry basis. These results are higher than the results reported by Jéssica et al. (2013) (321.05 mg GAE /100g dry basis) and lower than the results reported by Nazmi et al. (2014) (834.863 mg GAE /100 g dry basis)

It could be also observed that cape gooseberry had considerable amount of flavonoid content being $78.07 \mathrm{mg} / 100 \mathrm{~g}$ dry basis. However, the total flavonoids are found to be lower than those reported by Jéssica et al. (2013) who mentioned that the total flavonoid content in cape gooseberry was $99.25 \mathrm{mg} / 100 \mathrm{~g}$ dry basis

The antioxidant activity of the methanolic extract of fresh cape gooseberry was $76.83 \%$ as shown in Table (5). This result is in accordance with that found by Ramadan \& Mörsel (2007) who reported that the antioxidant activity in fresh cape gooseberry was78\% on fresh weight. Jéssica et al. (2013) mentioned that antioxidant capacity may be related to the amount of vitamin $C, B$-carotene, total phenolic and flavonoid content since these compounds act as scavengers of the free radicals produced during oxidation reactions. 
Fresh cape gooseberry contained a moderate amount of ascorbic acid (40.13 $\mathrm{mg} / 100 \mathrm{~g}$ ) on fresh weight basis, which was very close to that found by Abou-Gharbia \& Abou- Tour (2001) (39.50 mg/100g) and El Sheikha et al. (2008) (39.68 mg/100g) and lower than that reported by Ramadan \& Mörsel (2003) $(43 \mathrm{mg} / 100)$ while it was higher than that reported by Ozturk et al. (2017) who found that ascorbic acid content of golden berry samples have showed varied between $31.40-35.10 \mathrm{mg} / 100 \mathrm{~g}$.

Table 5. Bioactive compounds of fresh cape gooseberry

\begin{tabular}{|l|l|l|}
\hline \multirow{2}{*}{ Component } & \multicolumn{2}{|c|}{ Value* } \\
\cline { 2 - 3 } & \multicolumn{1}{|c|}{ fresh weight basis } & \multicolumn{1}{|c|}{ (dry weight basis) } \\
\hline Total phenolic content $(\mathrm{mg} / 100 \mathrm{~g}) * *$ & $106.38 \pm 0.45$ & $669.80 \pm 2.87$ \\
Total flavonoids $(\mathrm{mg} / 100 \mathrm{~g}) * * *$ & $12.38 \pm 0.67$ & $78.07 \pm 4.16$ \\
Antioxidant activity $(\%)$ & $76.83 \pm 1.38$ & --- \\
Ascorbic acid $(\mathrm{mg} / 100 \mathrm{~g})$ & $40.13 \pm 1.57$ & $253.03 \pm 9.93$ \\
B-carotene $(\mathrm{mg} / \mathrm{g})$ & $12.80 \pm 1.15$ & $80.71 \pm 7.28$ \\
chlorophyll A $(\mu \mathrm{g} / \mathrm{g})$ & $2.47 \pm 0.28$ & $15.56 \pm 1.77$ \\
chlorophyll $\mathrm{B}(\mu \mathrm{g} / \mathrm{g})$ & $3.64 \pm 0.17$ & $22.96 \pm 1.09$ \\
Total chlorophyll $(\mu \mathrm{g} / \mathrm{g})$ & $6.11 \pm 0.45$ & $38.52 \pm 2.84$ \\
\multicolumn{2}{|l}{} & \\
\hline
\end{tabular}

$*$ Mean of three replicates \pm SD $\quad * *$ Gallic acid equivalent $\quad * * *$ Rutin equivalent

High amounts of $\beta$-carotene were detected also in the cape gooseberry (Table 5). The $\beta$-carotene content of fresh cape gooseberry was $(12.8 \mathrm{mg} / \mathrm{g})$ on fresh weight basis. This value was higher than that previously reported by Vilbett et al. (2013) $(10.75 \mathrm{mg} / \mathrm{g})$ and Ramadan \& Mörsel (2007) $(4.32 \mathrm{mg} / \mathrm{g}$ ) and lower than that reported by Puente et al. (2011) (14.60 mg/100 g). Therefore, cape gooseberry could be a novel source for nutraceuticals or bioactive components of natural origin that can be utilised in food processing as natural additives and obviate the need for artificial additives.

Cape gooseberry contained low amounts of A, B and total chlorophyll (2.47, 3.64 and $6.11 \mu \mathrm{g} / \mathrm{g}$ sample), respectively (Table 5 ) which was lower than that mentioned by Abou-Gharbia \& Abou-Tour (2001) who found that the amount of total chlorophyll was $18.50 \mu \mathrm{g} / \mathrm{g}$ sample.

\section{Total soluble solids, $\mathrm{pH}$, total acidity and salt contents of processed cape gooseberry products}

Table (6) shows the TSS, pH, total acidity and salt contents in different processed products of cape gooseberry. The results showed that cape gooseberry jam had the highest total soluble solids (68 ${ }^{\circ}$ Brix) followed by Paste and Syrup (45.11, $\left.45.04{ }^{\circ} \mathrm{Brix}\right)$, respectively, while canned compote and appetizer (A) had the lowest total soluble solids (15.11, $\left.15.14^{\circ} \mathrm{Brix}\right)$, respectively. Addition of sugar was responsible for the increased value of TSS. According to the data in Table (6), the $\mathrm{pH}$ value in 
different products ranged between 3.40 in canned compote to 2.93 in jam and appetizer (B) products. Also the data in Table (6) revealed that the processed dehydrated cape gooseberry had the highest total acidity (5.32). This result was mainly due to the loss of moisture content during the dehydration process. The lowest total acidity was observed in nectar product. Appetizer (A) and (B) contained 2.5 and 3.1 salts, respectively, which is mainly due to addition of salt during the processing of these products. In general, these results depended on the type and method of processing of these products

Table 6. Total soluble solids, $\mathrm{pH}$, total acidity and salt of processed cape gooseberry products.

\begin{tabular}{|l|c|l|l|c|}
\hline \multirow{2}{*}{ Cape gooseberry products } & \multicolumn{4}{|c|}{ Properties *** } \\
\cline { 2 - 5 } & \multicolumn{1}{|c|}{ TSS ( ${ }^{\circ}$ Brix) } & pH & Total acidity (\%) & Salt \\
\hline Canned compote & $15.11 \pm 0.11$ & $3.40 \pm 0.03$ & $0.89 \pm 0.00$ & - \\
\hline Nectar & - & $3.10 \pm 0.03$ & $5.32 \pm 0.11$ & - \\
\hline Syrup & $16.03 \pm 0.05$ & $3.63 \pm 0.02$ & $0.26 \pm 0.01$ & - \\
\hline Paste & $45.04 \pm 0.07$ & $3.18 \pm 0.60$ & $0.86 \pm 0.01$ & - \\
\hline Jam & $45.11 \pm 0.10$ & $3.40 \pm 0.02$ & $1.40 \pm 0.25$ & - \\
\hline Appetizer (A)* & $68 \pm 0.00$ & $2.93 \pm 0.03$ & $0.60 \pm 0.01$ & - \\
\hline Appetizer (B)** & $15.14 \pm 0.12$ & $3.33 \pm 0.03$ & $1.17 \pm 0.10$ & $2.5 \pm 0.10$ \\
\hline Appetred fruits & $27.11 \pm 0.12$ & $2.93 \pm 0.03$ & $1.2 \pm 1.40$ & $3.1 \pm 0.15$ \\
\hline
\end{tabular}

Appetizer (A)*: Cape gooseberry sauce with vegetables

Appetizer (B)**: Cape gooseberry sauce with ketchup spices

$* * *$ Mean of three replicates \pm SD on fresh weight basis

\section{Some bioactive compounds of processed cape gooseberry products.}

Table (7) shows some bioactive compounds including total polyphenols, total flavonoids, antioxidant activity and $\beta$-carotene of processed cape gooseberry products.

The highest amount of polyphenols (on fresh weight basis) was found in dehydrated cape gooseberry product $(238.99 \mathrm{mg} / 100 \mathrm{~g}$ ) followed by appetizer B $(133.61 \mathrm{mg} / 100)$ and appetizer A (125.55mg/100g) while the lowest amount was recorded in jam and nectar being 40.80 and $20.46 \mathrm{mg} / 100 \mathrm{~g}$, respectively. The syrup, paste and canned compote products contained 43, 70.52 and $94.08 \mathrm{mg} / 100 \mathrm{~g}$, respectively.

Also, the data in Table (7) showed that total flavonoid content of different processed cape gooseberries products was highest amount $54.16 \mathrm{mg} / 100 \mathrm{~g}$ in dehydrated fruit and $3.38 \mathrm{mg} / 100 \mathrm{~g}$ in nectar product (lowest amount. The appetizer (B), (A) and canned compote products contained high amounts of total flavonoids which recorded $21.99,18.35$ and $11.98 \mathrm{mg} / 100 \mathrm{~g}$, respectively. On the other hand, the paste, syrup and jam products contained low amounts of total flavonoids which recorded $7.55,5.28$ and $4.26 \mathrm{mg} / 100 \mathrm{~g}$, respectively. 
Table 7. Some bioactive compounds of processed cape gooseberry products.

\begin{tabular}{|c|c|c|c|c|}
\hline \multirow[b]{2}{*}{$\begin{array}{c}\text { Cape } \\
\text { gooseberry } \\
\text { products }\end{array}$} & \multicolumn{4}{|c|}{ Bioactive compounds*** } \\
\hline & $\begin{array}{c}\text { Total phenolic content } \\
\mathbf{m g} / \mathbf{1 0 0 g}\end{array}$ & $\begin{array}{r}* * * * * \\
\text { Total flavonoids } \\
\mathbf{m g} / \mathbf{1 0 0 g}\end{array}$ & $\begin{array}{l}\text { an } \\
\text { tioxidant } \\
\text { activity } \\
(\%)\end{array}$ & $\begin{array}{c}\text { B-carotene } \\
\mathrm{mg} / \mathrm{g}\end{array}$ \\
\hline $\begin{array}{l}\text { Canned } \\
\text { compote }\end{array}$ & $94.08 \pm 3.07$ & $11.98 \pm 0.54$ & $65 . .43 \pm 1.05$ & $12.34 \pm 0.53$ \\
\hline Dehydrated fruit & $238.99 \pm 4.18$ & $54.16 \pm 0.57$ & $83.55 \pm 2.55$ & $22.53 \pm 0.34$ \\
\hline Nectar & $20.46 \pm 2.43$ & $3.38 \pm 0.59$ & $19.63 \pm 2.31$ & $4.44 \pm 0.74$ \\
\hline Syrup & $43.00 \pm 1.67$ & $5.28 \pm 0.58$ & $32.25 \pm 2.11$ & $6.44 \pm 0.48$ \\
\hline Paste & $70.52 \pm 1.35$ & $7.55 \pm 0.54$ & $46.65 \pm 1.65$ & $11.90 \pm 0.56$ \\
\hline Jam & $40.80 \pm 2.7$ & $4.26 \pm 0.36$ & $24.76 \pm 1.22$ & $3.11 \pm 0.87$ \\
\hline Appetizer (A)* & $125.55 \pm 1.16$ & $18.35 \pm 0.23$ & $78.34 \pm 2.11$ & $17.19 \pm 0.18$ \\
\hline Appetizer (B)** & $133.61 \pm 1.02$ & $21.99 \pm 2.24$ & $80.21 \pm 1.45$ & $13.89 \pm 0.89$ \\
\hline
\end{tabular}

Appetizer (A)*: Cape gooseberry sauce with vegetables.

Appetizer (B) **: Cape gooseberry sauce with ketchup spices .

$* * *$ Mean of three replicates \pm SD on fresh weight basis.

**** Gallic acid equivalent $\quad * * * * *$ Rutin equivalent

Antioxidant activity of processed cape gooseberry products varied between $19.63-83.55 \%$ (Table 7). These results depended on type, ingredients and method of processing of deferent products. Some of the medicinal properties of the fruit of $P$. peruviana L. are associated with the fruit's antioxidant capacity (Puente et al., " "l!.

According to the data in Table (7), $\beta$-carotene content in different cape gooseberry products showed high amounts in dehydrated fruit appetizer (A) , appetizer (B) canned compote and paste recording 22.53, 17.19, 13.89,12.34 and $11.90 \mathrm{mg} / \mathrm{g}$, respectively while syrup, nectar and jam contained low amounts recording $6.44,4.44$ and $3.11 \mathrm{mg} / \mathrm{g}$, respectively. $B$-carotene is very important in the prevention of certain human diseases such as cancer. The reason that carotenoids prevent cancer is related to the antioxidant activity that deactivates free radicals generated in tissues (Castro et al., 2008).

In general, the highest amount of total polyphenols, flavonoids (as $\mathrm{mg} / 100 \mathrm{~g}$ ), antioxidant activity $(\%)$ and $B$-carotene as $(\mathrm{mg} / \mathrm{g})$ in appetizer $(A)$ and $(B)$ may be related to the food ingredients used for their preparation: vegetables, herbs and spices

\section{Sensory evaluation of processed cape gooseberry products.}

Table (8) summarizes the sensory evaluation including colour, taste, odour, texture, appearance and overall acceptability of eight processed cape gooseberry products. Generally, all the products were accepted by the panelists. The description of the overall acceptability by the panelists was extremely acceptable. Fig (3) illustrates the products manufactured from the cape gooseberry fruits. 
Table 8. Sensory evaluation of processed cape gooseberry products

\begin{tabular}{|l|c|c|c|c|c|c|}
\hline $\begin{array}{c}\text { Cape gooseberry } \\
\text { Products }\end{array}$ & Colour & Taste & Odour & Texture & Appearance & $\begin{array}{c}\text { Overall } \\
\text { acceptability }\end{array}$ \\
\hline Canned compote & $8.88 \pm 0.33$ & $8.11 \pm 1.05$ & $8.0 \pm 0.87$ & $8.44 \pm 0.53$ & $8.89 \pm 0.33$ & $8.46 \pm 0.35$ \\
\hline Dehydrated & $8.22 \pm 0.66$ & $7.78 \pm 0.97$ & $7.78 \pm 0.67$ & $7.67 \pm 0.71$ & $8.11 \pm 0.33$ & $7.91 \pm 0.40$ \\
\hline Nectar & $8.55 \pm 0.53$ & $8.44 \pm 0.53$ & $8.33 \pm 0.70$ & $8.44 \pm 0.53$ & $8.66 \pm 0.50$ & $8.49 \pm 0.25$ \\
\hline Syrup & $8.77 \pm 0.44$ & $8.33 \pm 1.00$ & $8.22 \pm 0.83$ & $8.11 \pm 0.60$ & $8.66 \pm 0.50$ & $8.42 \pm 0.52$ \\
\hline Paste & $8.00 \pm 0.70$ & $7.78 \pm 0.83$ & $8.44 \pm 0.73$ & $8.33 \pm 0.5$ & $7.88 \pm 0.78$ & $8.09 \pm 0.55$ \\
\hline Jam & $8.67 \pm 0.50$ & $9.00 \pm 0.00$ & $8.77 \pm 0.44$ & $9.00 \pm 0.0$ & $8.78 \pm 0.444$ & $8.84 \pm 0.19$ \\
\hline Appetizer (A)* & $8.00 \pm 0.71$ & $8.11 \pm 1.17$ & $8.11 \pm 0.78$ & $8.66 \pm 0.5$ & $8.33 \pm 0.71$ & $8.24 \pm 0.60$ \\
\hline Appetizer (B)** & $8.22 \pm 0.83$ & $8.22 \pm 0.83$ & $8.44 \pm 0.73$ & $8.33 \pm 0.71$ & $8.22 \pm 0.67$ & $8.29 \pm 0.66$ \\
\hline
\end{tabular}

Appetizer (A)*: Cape gooseberry sauce with vegetables

Appetizer (B)**: Cape gooseberry sauce with ketchup spices

\section{CONCLUSION}

Cape gooseberry fruit could be considered a suitable plant for different food applications. In the present study, useful information about the industrial application of cape gooseberry in the production of canned compote, dehydrated fruit, nectar, syrup, paste, jam, appetizer (A) and (B) are provided. All products were highly accepted by the panelist's importance who gave high scores to the products. This will be interesting as an indication of the potentially nutraceutical of cape gooseberry as a rich source of bioactive phytochemicals and functional foods. Cape gooseberry can be a very interesting candidate for the processing of new functional foods and drinks.

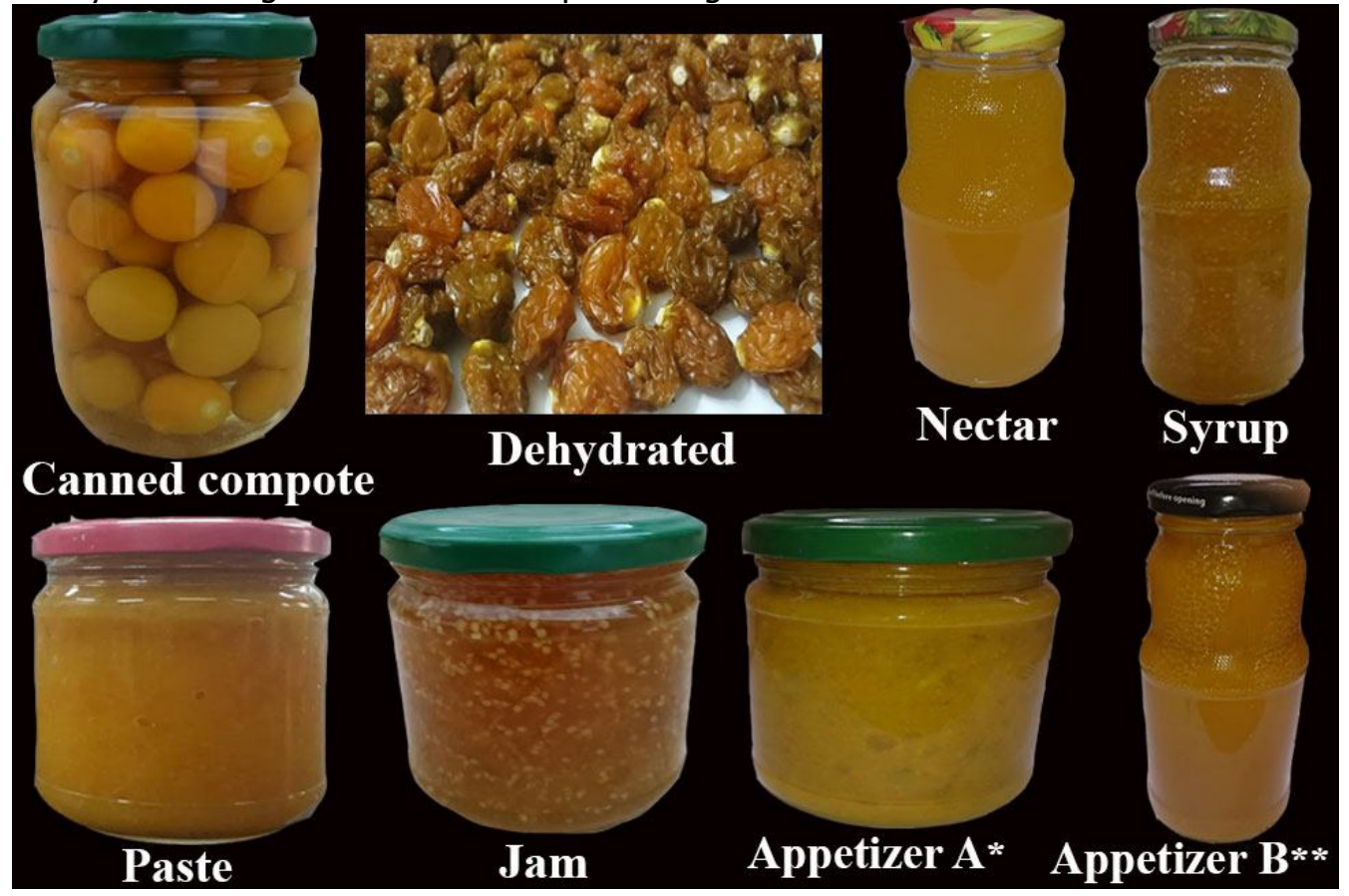

Fig. 3. Cape gooseberry products

*Appetizer A: Cape gooseberry sauce with vegetables

** Appetizer B : Cape gooseberry sauce with ketchup spices 


\section{Acknowledgements}

The author is grateful to Edfina Company for preserved foods in Alex., for providing experimental facilities and laboratory support. The author particularly acknowledges the continuous support of Eng. Ibrahim Abdel Azez Ibrahim, Research, Development \& Quality control General Manager

\section{REFERENCES}

1. Abeer I. Shabana. 2016. Organic husk tomato ( $p$ hysalis peruviana,l) Production for exportation. J. Plant Production, Mansoura Univ.,7 (8): 843 - 850.

2. Abou-Farrag, H.T., Abdel-Nabey, A.A., Abou-Gharbia, H.A. \& Osman, H.O.A 2013. Physicochemical and Technological Studies on Husk Tomato (Physalis pruinose L.) Alexandria science exchange journal, 34(2):204-221

3. Abou-Gharbia, H.A. \& Abou-Tour, E.M. 2001. Properties and processing of husk tomato (Physalis pruinosa L.). Minufiya J. Agric. Res., 26: 761-781.

4. Association of Official Analytical Chemists (AOAC) 2003.Th Official methods of analytical. Helrich, K. $17^{\text {th }}$ ed. Virginia, USA.

5. Association of Official Analytical Chemists (AOAC) 2000. Th Official methods of analytical. 17 ed. Gaitherburg: Maryland, USA.

6. Bakry, N.A. 2003. The Chemical Composition and Processing of Goldenberry (Physalis peruviana) grown in Egypt. M. Sc. Thesis, Public Health science (food analysis). High Institute of Public Health. Alex. Univ., Egypt.

7. Brand-Williams, W, Cuvelier, M, E \& Berset,C. 1995. Use of free radical method to evaluate antioxidant activity. Lebensm Wiss Technology, 28: 25-30

8. Castro, A., Rodriguez, L., \& Vargas, E. 2008. Dry gooseberry (Physalis peruviana L) with pretreatment of osmotic dehydration. Vitae - Revista de la Facultad de Química Farmacéutica, 15(2), 226-231.

9. El Sheikha ,A., Zaki , M., Bakr, A., Magida , E, H. \& Montet, M., 2008 Physicochemical Properties and Biochemical Composition of Physalis (Physalis pubescens L.) Fruits. Global Science Books, 124-130

10. El-Sheikha, A.F., Ribeyre, F., Larroque, M., Reynes, M. \& Montet, D. 2009. Quality of physalis (physalis pubescens I.) juice packaged in glass bottles and flexible laminated packs during storage at $5^{\circ} \mathrm{C}$. African Journal of Food, Agriculture, Nutrition and Development,9(6): 1684-5374

11. Hassanien, M.F.R. 2011. Physalis peruviana : A rich source of bioactive phytochemicals for functional foods and pharmaceutical. Food Reviews International, 27(3):259-273. 
12. Jéssica ,L., Antonio, V, G., María, J, T., Roberto, L,M., Issis, Q,F., \& Karina, D, S.2013. Effect of dehydration temperature on physico chemical properties and antioxidant capacity of goldenberry (Physalis peruviana L.). Chilean Journal of Agricultural Research, 73(3).

13. Khurmi, R.S. 1982. Fluid Mechanics, Chand S Co., Ltd., Ram Nagar, New Delhi, 4 $\mathrm{pp}$

14. Kramer, A. \& Twigg, B. A. 1970. Quality Control for the Food Industry, Vol. 1. Fundamentals, 3rd Ed., The AVI Publishing Company, Inc., Westport, Connecticut, XVI, 244.

15. Maurya, S. \& Singh, D. 2010. Quantitative analysis of total phenolic content in adhatoda vasica nees extracts. International Journal of Pharm.Tech .Research. 2, (4): 2403-2406.

16. Moran, R., \& Porath,D. 1980. Chlorophyll determination in intact tissues using N,NDimethylformamide . Plant Physiol. 65, 478-479

17. Mustafa, A. M. M. 2009. Effect of Nitrogen, Potassium Fertilization and Their Interactions on Yield and Quality of Husk Tomato. MSc. Thesis, Fac. Agric. Alexandria University.

18. Nazmi , I., GÖkçen, Y., Halil, Ü., Eşref, I \& Vildan, U. 2014. Effect of different drying methods on drying characteristics, colour, total phenolic content and antioxidant capacity of Goldenberry (Physalis peruviana L.), International Journal of Food Science and Technology 49, 9-17

19. Ozturk, A., Zdemir,Y., Albayrak, B., Simşek, M. \& Yildirim, K. C. 2017. Some nutrient characteristics of goldenberry (physalis peruviana L.) cultivar candidate from turkey . Scientific Papers. Series B, Horticulture. Vol. LXI

20. Perry L.M., Metzger J.1980 Medicinal plants of East and Southeast Asia, Attributed Properties and Uses (Vol. 620). MIT Press, Cambridge, London.

21. Piggott, J.R., 1984. Sensory Analysis of Foods. Elsevier Applied Science Publishers, New York, USA. pp. 157-161.

22. Puente, L. A., Pinto-Muñoz, C. A., Castro, E. S. \& Cortés, M. 2011. Physalis peruviana Linnaeus, the multiple properties of a highly functional fruit: A review. Food Research International - Journal 44(7):1733-1740.

23. Ramadan M. F. \& Mörsel, J. T. 2007 "Impact of enzymatic treatment on chemical composition, physicochemical properties and radical scavenging activity of goldenberry (Physalis peruviana L.) Juice," Journal of the Science of Food and Agriculture, 87(3):452-460.

24. Ramadan, M. F., \& Mörsel, J., T. 2003. Oil goldenberry (Physalis perviana L.). Journal of Agricultural and Food Chemistry, 51, 969-974. 
25. Rodrigues, E , Ismael Ivan Rockenbach, I.,I,Luciano, C., Gonzaga, L, V., Chaves,E, S. \& Fett, R. 2009. Minerals and essential fatty acids of the exotic fruit Physalis peruviana L. Cienc. Tecnol. Aliment., Campinas, 29(3): 642-645.

26. Solange.,F.O., Fernando.,J. A. G., Paula., M. R. C. \& Raquel., P.F.G. 2015. Physical properties of Physalis Peruviana L. International conference on engineering, (1):55-59

27. Stary, F. 1983. Poisonous plants. Hamlyn colour Guides. Hamlyn, London. New York. Sydney, Toronto.

28. Steinmetz K.A.\& Potter J.D. 1996). Vegetables, fruit, and cancer prevention, A review, J. Am. Diet. Assoc., 96(10):1027-1039.

29. Swami, S. B., Thakor, N. J. \& Wagh, S. S.2013. Effect of temperature on viscosity of kokum, karonda, mango pulp and cashew apple syrup. Agricultural Engineering International: CIGR Journal . 15(4):281-287.

30. Vilbett, B., L, Claudia, G. V, Paola, F.A, Issis, Q.F \& Mario, P.W. 2013. Extraction of --Carotene, vitamin c and antioxidant compounds from Physalis peruviana (Cape Gooseberry) assisted by high hydrostatic pressure. Food and Nutrition Sciences, 4, 109-118.

31. Walts, B.M., Ylimaki, G.L. Jeffrey, L.E. \& Elias, L.G. 1989. Sensory Methods for Food Evaluation, IDRG, Ottawa, pp: 6-9, 60-79.

32. Wu S.J., Ng L.T., Huang Y.M., Lin D.L., Wang S.S., Huang, S.N. \& Lin C.C. 2005. Antioxidant of Physalis peruviana, Biol. Pharm. Bull. 28, 963-966.

33. Zarina, Z. \& Tan S. Y. 3013 Determination of flavonoids in Citrus grandis (Pomelo) peels and their inhibition activity on lipid peroxidation in fish tissue. International Food Research Journal, 20(1): 313-317. 


\title{
تقييم منتجات جليدة غير تقلياية مصنعة من الحرنكش
}

\author{
رضا عبد الحكيم عامر \\ قسم بحوث تصنبيع الحاصلات البستانية - معرة بحوث تكنولوجيا الاغذية - مركز البحوث

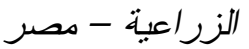

تعتبر ثمار (Physalis peruviana , L)

الو اعدة و المعروفة فى مصر بإسم الحرنكش و التى إكتسبت شعبية فى الأسو اق المتخصصة. إلا إنها تستخدم فى مصر كغذاء للنسالى فقط لذا تهدف هذه الدر اسة إلى الاستفادة من هذه الثمار فى إنتاج منتجات جديدة مثل الكمبوت ،الحرنكش المجفف، النيكتار ، الشراب المركز ، عجينه الفو اكهه، المربى ، فاتحات الثهية ـ نم دراسة كل من الخواص الفيزيائية ، الكيميائية ، التكنولوجية لثمار الحرنكش • ولقد وجد اللب حلو الطعم ( المواد الصلبة الذائبة 13.75) ذو طبيعة حامضبة ( قيمة الاس الهيدروجينى 3.7 و الحموضة التتقيطية 1,20 \% كحامض سيتريك) ، وتمثل السكريات غير المختزلة 52,95 من السكريات الكلية 56,24 ـ كما أظهرت النتائج ايضا أن ثمار الحرنكش تعتبر مصدراً جيدا للبيتا كاروتين و فيتامين ج و المركبات الفينولية و الفلافونويدات ومضادات الاكسدة بالاضافة الى بعض المعادن مثل البوتاسيوم و الماغنيسيوم و الحديد و الزنك ـ ـ ونتيجة لذلك تم استخدام

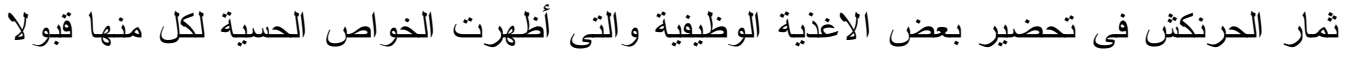

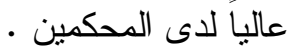


